\title{
The Validity of PjBL STEAM-based Themathic Learning Device Material for The Growth and Organism Developmnent for Elementary School Students
}

\author{
$1^{\text {st }}$ Sudarman ${ }^{1}, 2^{\text {nd }}$ Subuh Anggoro ${ }^{2}$ \\ \{ sudarmansragen@gmail.com ${ }^{1}$, subuhanggoro@ump.ac.id ${ }^{2}$ \} \\ Elementary School Karangnangka, Banyumas Regency ${ }^{1}$ \\ Graduate School, Universitas Muhammadiyah Purwokerto, Indonesia ${ }^{2}$
}

\begin{abstract}
This study aims to describe the vallidity of PjBL STEAM-based Thematic Learning Device Material for the Growth and Organism Development for Elementary School Students. Learning Device developed using the Analysis-Design-DevelopImplement-Evaluate (DDIE model from McGriff modified by Aldoobie, namely Analysis, Design, Develop without Implementation and Evaluation (ADDIE). Validity data obtained from experts and practitioners. The research result on the validity of the developed device showed that: 1) syllabus $90 \%$ (very valid), 2) Lesson Plan $90.35 \%$ (very valid), 3) teaching materials $93 \% \%$ (very valid), 4) Worksheet $91 \%$ ( very valid), and learning evaluation $89.39 \%$ (very valid). So, thematic learning device oriented to PjBL STEAM, the material for the growth and organism development of elementary school students is very valid and feasible to be widely implemented.
\end{abstract}

Keywords: thematic learning device, STEAM PjBL, growth and organism development

\section{Introduction}

Currently the world is getting more advanced and developing, especially in the education. Educational beginners conceptualize the development of 21 st century skills-oriented education and to achieve graduates who are able to compete in the era of the 4th industrial revolution (4IR) or "industry 4.0" [1][2][3].

In the 21st century skills are not only emphasized or applied at the secondary education level, but have now been introduced to the primary education level [4][2][5]. One of the characteristics of this application is the formation of a learning ability and innovation skill [6] [5]. Another distinctive feature is also shown by the presence of cutting-edge technologies that merge the physical, digital and biological worlds, which are manifested in a tangible form and can be utilized by the wider community [3].

Especially in the application of the 2013 curriculum, the term 21 st century skills is often referred to as $4 \mathrm{C}$, namely critical thinking skills, communication, collaboration, creativity and 
innovation [3][2]. The fact is that currently the 4C skills of students in Indonesia are still low [4] [3]. This is also supported by the Research Program Internationale for Student Assessment (PISA) in measuring what students know and what students can do or apply with their knowledge that is included in the 4C skill dimensions from 2000 to 2015 , showing the average score of students' scientific literacy. Indonesia is below the international average $(<500)$. Therefore, the need to train students' $4 \mathrm{C}$ thinking skills from an early age is important in learning activities [7].

Thematic learning at the elementary school level has the potential to achieve an expected 4C skill. This is very reasonable because in essence thematic learning reflects holistic problems in real life that foster power as well as the ability to think critically, creatively and solutions [5]. Through elementary school thematic learning, 4C skills such as communicating and collaborating can be realized properly [4][5].

Realize the importance of these 4C skills, in elementary school Thematic learning, currently it leads to an integrated STEAM approach in the fields of Science, Technology, Engineering, Art and Mathemathic studies [4][2] [5]. This opinion is also supported by the 2013 Curriculum document that one of the improvements to the Thematic learning that has been developed is the improvement of STEM or STEAM multidisciplinary learning patterns carried out with the PBL or PjBL model and strengthening learning patterns that provide growth in $4 \mathrm{C}$ abilities [8].

The form of study using STEM and STEAM PjBL learning device is widely used, but with different variables at the intermediate level that can train students' 4C skills [9][4][3]. Therefore, there is a need for further research at the basic education level in terms of the validity of STEAM PjBL-based Thematic learning device for growth and organism development for elementary schools, so that they can be used more widely to achieve the expected goals.

\section{Method}

The development model in this study is the ADDIE model, it's an Analysis (needs analysis and performance analysis), Design (designing learning device according to objectives), Develop (making a draft of learning devicce according to the 2013 curriculum, without the Implementation and Evaluation stages [10][24]. Validation of learning device to experts, it's Postgraduate Primary Education lecturers at Universitas Muhammadiyah Purwokerto of Purwokerto and practitioners, who is elementary school teachers who have implemented STEAM learning in class from the Wirayuda Cluster, Banyumas Regency [11].

$$
P=\frac{\text { Total Score }}{\text { Maximum Score }} \times 100 \% \quad[11] \text {. }
$$

*the total score is obtained from the total calculation of all items of the validation instrument consisting of aspects (feasibility of content, language, and presentation).

As a guideline decision making on the validity of learning devices the following assessment. 
Table 1. Criteria for the Validity of Learning Devices

\begin{tabular}{ccc}
\hline Percentage (\%) & Validity Criteria & Explanation \\
\hline $85,01-100,00$ & Very Valid & Can be used without revision \\
$70,01-85,00$ & Valid & Can be used with a little revision \\
$50,01-70,00$ & Less Valid & Can be used with multiple revisions \\
$01,00-50,00$ & Invalid & Can't be used and still requires consultation \\
\hline
\end{tabular}

\section{Results and Discussion}

The development of STEAM PjBL thematic learning device for the growth and organism development for elementary schools consists of syllabus, lesson plans, teaching materials, worksheets and learning evaluation. The following is a display of the learning device design in Figure 1.

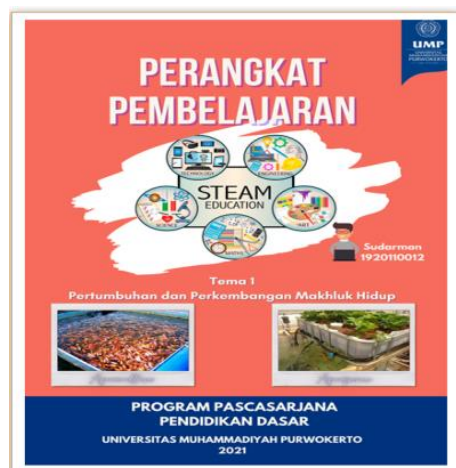

Fig 1. Display of STEAM PjBL Thematic Learning device Designs for the Growth and Organism Development for

Elementary Schools

The content of learning device is adjusted to practice 4C skills [12][3], such as the existence of a PjBL STEAM component in the syllabus, lesson plans, and teaching materials and worksheet has a Come Think feature which contains material evaluations to practice critical and creative thinking skills, Let's Think Critically and Creative designing investigative projects and technology products in the form of making aquaponic and hydroponic in training $4 \mathrm{C}$ students, presenting the results of technology projects to train communication and collaboration skills.

The Let's Read and Let's Observe features contain material to increase understanding and encourage students to learn about the growth and organism development as shown in Figure 2. 

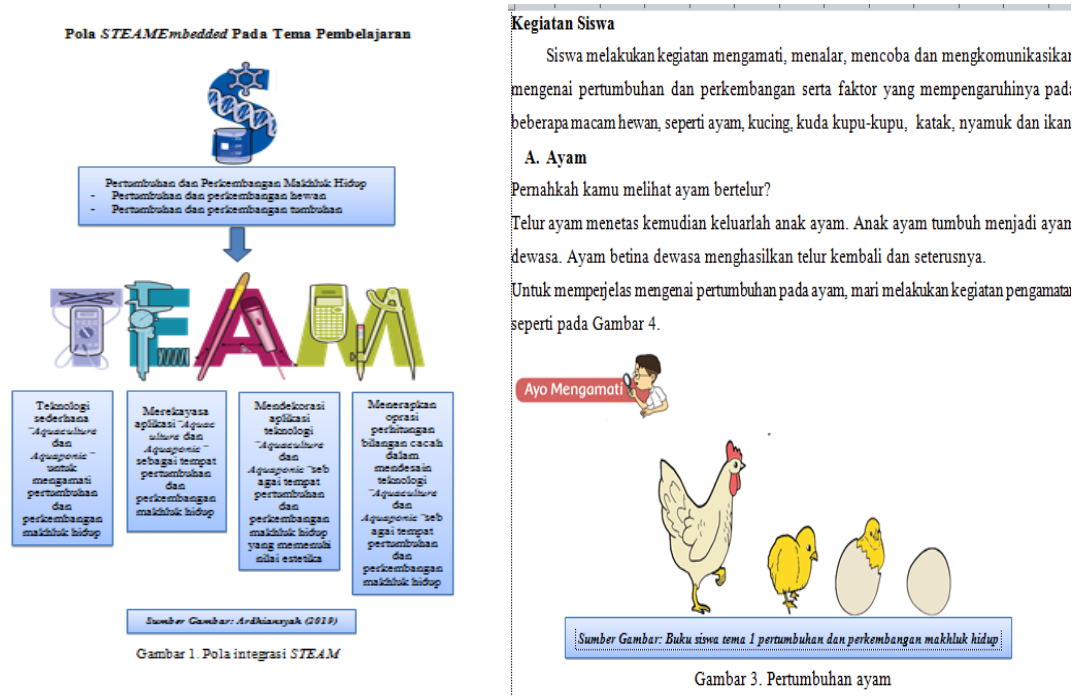

Kegiatan Guru

Terlebih dahulu guru mengaitcan kembali pengetahuan Science tentang pertumbuhan dan perkembangan pada ilan yang diaplikas ikan pada telmologi Aquacuiture. Selanjutnya guru mengarahkan pada siswa guna merancang teknologi tersebut. Teknologi Aquacuiureyang dibuat harus memiliki dua kriteria penting, yaitu: 1) sederhana dalam pelaksanaan dan 2) dapat untuk mengetahui pertumbuhan dan perkembangan ikan.

Kegiatan pembelajaran ini dilabsanakan den gan membagi beberapa kelorpok siswa untuk mencoba membuat proboip eAquaxwiur ed an menebar benin yang terdiri dari berbagai jenis ilan yang sudah ditulislan pada latihan konsep Science dan disebutkan pada konsep Technology serta mengkomunikasikan desain tersebut pada kelompok lain.

Kegiatan Siswa

Sis wa melabukan kegiatan menco ba membuat prosotiped quacuitured man mebar benih yang terdiri dai berbagai jenis ilan serta mengkommilasilan desain tersebut pada lelompolc lain.

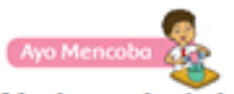

Merekayasa desain danprototipeAquaculture serta menebar benih ilan!

1. Membuat desain Aquaculture

Alat: Penggaris dan pensil Bahan: Buku gambar

Langkah kerja:

1) membuat garis lurus dengan pensil seperti bentuk persegi panjang pada buku gambar

2) membuat sekat didalam gambar

3) memberikan keterangan masing-masing selat untuk di isi macam-macam benih ikan seperti pada gambar dibawah ini

4) Mempresentasikan hasil desain tersebut pada kelompok lain.

Fig 2. Contents of PjBL STEAM-Based Thematic Learning Materials for the Growth and Organism Development for Elementary Schools 
After compiling learning device with signs to practice $4 \mathrm{C}$ skills, they were validated by two experts and two learning practitioners. The following are the validation results of learning device by learning experts and practitioners in Table 2 .

Table 2. Learning Device Validation Result by Experts and Practitioners

\begin{tabular}{|c|c|c|c|c|c|c|c|}
\hline \multirow[t]{2}{*}{ No. } & \multirow{2}{*}{$\begin{array}{l}\text { The apects that } \\
\text { are vallidated }\end{array}$} & \multicolumn{4}{|c|}{ Validators' Average Rating } & \multirow[t]{2}{*}{ Average } & \multirow[t]{2}{*}{ Criteria } \\
\hline & & Expert 1 & Expert 2 & Practioners1 & Practioners2 & & \\
\hline 1. & Syllabus & $89,23 \%$ & $87,69 \%$ & $90,77 \%$ & $92,31 \%$ & $90 \%$ & Very valid \\
\hline 2. & Lesson Plans & $90 \%$ & $88,57 \%$ & $91,43 \%$ & $91,43 \%$ & $90,35 \%$ & Very valid \\
\hline 3. & Learning Materials & $93 \%$ & $92 \%$ & $94 \%$ & $93 \%$ & $93 \%$ & Very valid \\
\hline 4. & Worksheet & $90 \%$ & $88 \%$ & $92 \%$ & $94 \%$ & $91 \%$ & Very valid \\
\hline 5. & $\begin{array}{l}\text { Learning } \\
\text { evaluation }\end{array}$ & 86,67 & $88,89 \%$ & $88,89 \%$ & $91,11 \%$ & $89,39 \%$ & Very valid \\
\hline
\end{tabular}

Based on information in Table 2 above, it is known that the learning device is very valid criteria or in other words it can be widely implemented. In general Factors that affect the results of the validity of learning device become very valid [13][14][15], due to making adjustments: 1) indicators set on the validity instrument, 2) content and theory according to the furmulatio basis of objectives and in terms of construct between components which are arranged systematically, and 3) the existence of a form of integration of the PjBL STEAM makes the positive value of the validator interested in giving an assessment. This opinion is supported by research [15][16], that in order to obtain good validity results, learning device products must adjust the criteria in the validator assessment items and pay attention to the complexity of students' thinking levels and the competence of teachers implementing learning products.

Factors specifically that affect the assessment are very valid in learning devices [3][17][18], because the making adjusts the Subject Specific Pedagogy (SSP) criteria for STEAM PjBL learning which has a component in training students' $4 \mathrm{C}$ (critical and creative thinking). As follows:

1) The syllabus contains: a) core competencies by paying attention to the hierarchy disciplines concept / material difficulties and the relationship between core competencies and basic competencies, b) basic competencies, c) the main material for the growth and organism development to be developed based on STEAM PjBL by paying attention to physical development, intellectual, emotional, social and benefits for students and environmental demands, d) learning experiences that contain learning scenarios in training critical and creative thinking skills, e) indicators that describe basic competencies, f) types of assessment using test and non-test forms, and $\mathrm{g}$ ) the latest learning resources from relevant books and articles related to the material on the growth and organism development

2) Lesson Plans contains: a) the formulation of learning objectives is clear, complete, logically structured encourages students to practice critical and creative thinking skills, b) a clear description of the material, in accordance with the learning objectives, student characteristics and scientific development, c) learning scenarios from activities (introduction, core, and coclusion) in detail, complete and learning steps reflect PjBL STEAM learning, d) learning 
steps to optimize the learning media for the surrounding environment according to the characteristics of PjBL STEAM learning optimally, enabling the formation of critical and creative thinking skills, e) An explisit learning techniques in learning steps accoriding to learning objectives f) completeness of lesson plans in procedures and assessment types according to learning objectives, and g) varied assessment instruments (tests and non-tests). This good PjBL STEAM RPP makes the initial determinant of students gaining knowledge as well as skills in independent projects so that they can be useful later in life around them, therefore a design that really fits the needs of students is needed [19]

3) The teaching materials include: a) the results of the 2013 Thematic learning curriculum analysis on the objectives of the material for the growth and organism development which are packaged in STEAM PjBL-based learning; $b$ ) titles that is adjusted to basic competencies and the main material to be studied, c) contents with short, concise, clear, scientific sentences, and d) various learning resources from relevant books and articles related to the digestive system material that can enrich the content teaching materials. The special characteristic of PjBL STEAM teaching materials that may not be found in other teaching materials is that they are contextual by making explicit various activities that lead to HOTS (High Order Thinking Skill) thinkers. These characteristics make students more active, independent and productive in uncovering scientific facts in life.

4) Evaluation instruments made in worksheets form, critical thinking tests and non-tests in observation sheets form for creative thinking skills. In the worksheet there is a STEAM concept that is applied by making products that are useful for daily life as well as the process of scientific inquiry in every step of the student's activities. The application of the STEAM concept by making products makes a characteristic that distinguishes it from STEAM-based worksheets which previously focused on integrating STEM aspects in learning materials, without any products that can be used in everyday life [22][23][25]. The critical thinking test by paying attention to the guidelines in accordance with the provisions [7], It is about : a) not only related to the concept of the curriculum so that it contains a broader concept, b) contains information in the form of data presentation for students to process, c) must make students able processing science content information. Another characteristic contained in the critical thinking test is the modification by inserting the application context in the student's real life which allows for innovation in previous assessments that have never been made by teachers and previous research related to critical thinking assessment instruments as well as being expected to be added value as an effort to identify misconceptions about the material. learning. The observation sheet for creative thinking skills that has been made has adjusted several general criteria by taking into account external and internal factors that are the impact of growing student creativity in learning activities as well as the utilization of the school's local potential. 


\section{Conclusion}

Based on the results and discussion in the description above, the development of STEAM $\mathrm{PjBL}$ thematic learning device for the growth and organism development for elementary schools is said to be very valid and feasible to be widely implemented.

\section{References}

[1] Zubaidah, S. :Keterampilan Abad ke-21: Keterampilan yang diajarkan Melalui Pembelajaran. Prosiding Seminar Nasional "Isi-Isu Strategis Pembelajaran MIPA Abad 21", pp. 1-17 (2016)

[2] Zubaidah, S. :STEAM (Science, Technology, Engineering, Arts, and Mathemathic): Pembelajaran untuk Memberdayakan Keterampilan Abad 21. Seminar Nasional Matematika dan Sains FKIP Universitas Wiralodra Indramayu September 2019, pp 1-18 (2019).

[3] Kurniahtunnisa :Pengembangan Perangkat Pembelajaran Materi Sistem Pernapasan dengan STEM Project Based Learning untuk Melatih Kemampuan 4C Siswa (Tesis). Semarang: Universitas Negeri Semarang (2019).

[4] Azizah, W.A., Sarwi \& Ellianawati :Pendekatan STREAM terhadap Kemampuan Berpikir Kritis Siswa Sekolah Dasar. Seminar Nasional Pascasarjana UNNES 2019. pp 1-6 (2019).

[5] Haifaturrahmah., Hidayatullah., Maryani, S., \& Nurmiwati :Pengembangan Lembar Kerja Siswa Berbasis STEAM untuk Sekolah Dasar. Jurnal Kependidikan. Vol. 6 (2), pp. 310-318 (2020).

[6] Martinez, J. E. :The Search for Method in STEAM Education (2017) https://doi.org/10.1007/978-3$\underline{319-55822-6}$

[7] OECD :PISA 2015 Result: Executive Summary. New York: Colombia University (2016).

[8] Kemendikbud :Konsep dan Implementasi Kurikulum 2013. Jakarta: Kementrian Pendidikan dan Kebudayaan (2014).

[9] Furi, L. M. I., Handayani, S., \& Maharani, S :Eksperimen Model Pembelajaran Project Based Learning dan Project Based Learning Terintegrasi STEM untuk Meningkatkan Hasil Belajar Siswa dan Kreativitas Siswa pada Kompetensi Dasar Teknologi Pengolahan Susu. Jurnal Penelitian Pendidikan, Vol. 35(1), (2018). https://doi.org/https://doi.org/10.15294/ipp.v35i1.13886

[10] Aldoobie, $\mathrm{N}$ :ADDIE Model. American International Journal of Contemporary Research. Vol. 5(6), pp. 68-72 (2015).

[11] Sugiyono :Statistika untuk Penelitian. Bandung: CV. ALFABETA (2015).

[12] Baker, E., Trygg, B., Otto, P., Tudor, M., \& Ferguson, L. Project-Based Learning Model Relevant Learning Relevant Learning for the 21 st Century, (2011).https://doi.org/10.5897/AJB11.3491

[13] Sari, B.K. :Desain Pembelajaran Model ADDIE dan Implementasinya dengan Teknik JIGSAW. Prosiding Seminar Nasional Pendidikan "Desain Pembelajaran di ERA ASEAN Economic Community (AEC) untuk Pendidikan Indonesia Berkemajuan”, pp. 87-102 (2017).

[14] Setiyadi, M.W :Desain Model Pengembangan Perangkat Pembelajaran Biologi. Jurnal Ilmiah Pendidikan Nuansa. Vol. 6(2), pp. 33-46 (2018).

[15] Wijayanti, A., \& Fajriyah, K :Implementasi STEM Project Based Learning untuk Meningkatkan Keterampilan Kerja Ilmiah Mahasiswa Calon Guru SD. Jurnal Pendidikan Sains (JPS), Vol. 06(2), pp. 62-69 (2018).

[16] Dewi, F.I. Validitas Perangkat Pembelajaran Berbasis Literasi Sains pada Materi Virus Kelas X SMA. Jurnal BioEdu. Vol. 5(3) ,pp. 166-173 (2016). 
[17] Osman, K., \& Saat, R. M :Editorial. Science technology, engineering and mathematics (STEM) education in Malaysia. Eurasia Journal of Mathematics, Science and Technology Education, Vol, 10(3), pp. 153-154, (2014). https://doi.org/10.12973/eurasia.2014.1077a

[18] Williams, J :STEM Education: Proceed with Caution. Design and 120 Technology Education: An International Journal, Vol. 16(1), pp. 26-35, (2011) https://doi.org/10.1002/ijc.1437

[19] Tati, T., Firman, H., \& Riandi, R :The Effect of STEM Learning through the Project of Designing Boat Model toward Student STEM Literacy. Journal of Physics: Conference Series, Vol. 895(1), pp. 1-8, (2017) https://doi.org/10.1088/1742-6596/895/1/012157

[20] Rustaman, N. Y., Afianti, E., \& Maryati, S. :STEM Based Learning to Facilitate Middle School Students' Conceptual Change, Creativity and Collaboration in Organization of Living System Topic. Journal of Physics: Conference Series, Vol. 1013(1), pp. 1-8, (2018) https://doi.org/10.1088/1742-

[21] Istikomayanti, Y \& Mitasari, Z :Miskonsepsi Materi Sistem Pencernaan Makanan dan Peranan Kompetensi Pedagogik Guru Pada Siswa Kelas VIII MTs di Kota Malang. Jurnal Pendidikan Biologi Indonesia. Vol. 3(2), pp. 103-113 (2017).

[22] Septiani, A :Penerapan Asesmen Kinerja dalam Pendekatan STEM (Sains, Teknologi, Enginering, dan Matematika) untuk Mengungkap Keterampilan Proses Sains. Prosiding Seminar Nasional "Isuisu Kontemporer Sains, Lingkungan, dan Inovasi Pembelajarannya”, pp. 654-659 (2017).

[23] Sulistiyowati., Abdurrahman \& Jalmo, T :The Effect of STEM-Based Worksheet on Students' Science Literacy. Jurnal Keguruan dan Ilmu Tarbiyah. Vol. 3(1), pp. $89-96$ (2018).

[24] McGriff, S.J :Instructional System Design (ISD): Using the ADDIE Model. Pensilvania: Penn State University (2000).

[25] Padliyyah SH, Suwarma IR, Jauhari A. Integration of Self-diagnosis in Pascal Law Learning Using STEM Approach. Dinamika Jurnal Ilmiah Pendidikan Dasar. 2021 Mar 6;12(2):104-10. 